\title{
The Crucial Point in Time Where Thai Students Are Introduced English Language Writing
}

\author{
Bayatee Dueraman ${ }^{1}$ \\ ${ }^{1}$ Faculty of Humanities and Social Sciences, Southern College of Technology, Nakhorn Si Thammarat, Thailand \\ Correspondence: Bayatee Dueraman, Faculty of Humanities and Social Sciences, Southern College of \\ Technology, 124/1, Thung Song-Huay Yod Rd. Thung Song, Nakhorn Si Thammarat, Thailand. Tel: \\ 66-831-806-739. E-mail: bayatee2554@gmail.com
}

\author{
Received: May 5, 2015 Accepted: August 8, 2015 Online Published: August 11, 2015 \\ doi:10.5539/elt.v8n9p96 URL: http://dx.doi.org/10.5539/elt.v8n9p96
}

\begin{abstract}
There have been interests in finding appropriate ways in which students learn to write in English as a second or foreign language (ESL/EFL). Educators should be aware that ESL/EFL learners are less privileged in terms of exposure to the target language when compared to their English native speaker counterparts. Ironically, writing instructions to date are based on first language writing theory. This paper aims at examining relevant factors which instigate Thai EFL learners to write English in their home country where it is not commonly used in both media and daily communication. The data were collected from seven English majors and two writing teachers from two leading universities in Thailand through an open-ended questionnaire and interviewed and relevant documents. Then, they were analysed qualitatively. Results showed that only students who chose to major in English at universities in Thailand were given opportunities to experience writing skills. Theoretical lacks in existing literature related to introduction of English writing to ESL/EFL learners and how the present argument fulfills the gap were highlighted. Towards the end, it concludes with some insights for teachers and educators of students who live in similar EFL contexts. It is hoped that an informed and systematic implementation of English curriculum in Thailand will be materialized.
\end{abstract}

Keywords: writing factors, writing instruction, EFL learners

\section{Introduction}

In many ways, students learn to write in English as a second or foreign language (ESL/EFL) differ from those who learn it as a native language (Williams, 2005). This is due to native English speakers (NES) are more privileged with the language environment long before they are introduced to writing while their ESL/EFL learners are not. Every day even before entering schools, the NESs have ample opportunities to listen, speak and interact in English while the others do not. This means that the NESs possess some or many English vocabulary words in their working memory though writing is not commonly taught at home. As for the case of EFL learners, English words are usually first introduced formally at schools. Nevertheless, the introduction of English to them varies from one school to another. More often than not these students were taught structure, grammar and vocabulary through reading or memorizing but not having direct access to the real use of language in their own environment. English writing as the most difficult skill to learn, is often neglected by English language teachers in Thailand.

It would be easier for EFL writing teachers to refer to what theories explain about the time that is best to introduce English writing to their students. Unfortunately, existing literature on writing skills only describes writing actions either in the form of a solitary activity or a dynamic interplay between students and their writing community (Berlin, 1988; Flower \& Hayes, 1981; Vygotsky, 1978; Bennui, 2008; Watcharapunyapong \& Usaha, 2013). None of this literature has ever pointed the special point in time where EFL learners begin to learn the skills in their own contexts. Within the above mentioned circumstances, there is a need to explore how and when writing skills is introduced to EFL learners. Findings of this study will benefit policy makers, English educators and writing teachers to understand factors that act as a driving force which instigates Thai EFL learners to write in their home country where English is not commonly used in both media and daily communication. Results 
gained from this study would offer better explanations concerning Thai students' problems in English writing skills as claimed by Glass (2008) and Watcharapunyawong and Usaha (2013). Subsequently, appropriate remedies can be executed for future development. Thus, the present study is guided by one research question with two sub-questions below.

1) How do Thai EFL students begin to experience English writing?

2) When do they learn to write?

3) What are other related factors to explain their first writing experience?

\section{Thai Education and the Teaching of English Language Writing Skills}

Writing involves more than just putting words down on paper. It needs several skills before one can really produce a piece of text. These include language, strategic, and critical thinking skills. Any education system that aims to promote all of these skills in students is also in support of the teaching writing skills while the opposite is not. In Thailand, it has been reported that the Thai education system is not compatible with the teaching of writing skills (Glass, 2008; Bennui, 2008). This maybe in part due to most English teachers who work in high schools or secondary schools are not qualified (Glass, 2008; Dueraman, 2012). Some cannot speak or produce even one paragraph in English. This adds to more difficulties in introducing English writing skills to students in pre-university life. In terms of their teaching approach, English teachers who cannot speak or write in English language can only do reading, grammar and translation but no writing or interactive speaking activities. They opt to use Thai as a medium of instruction. This is not surprising why better privileged schools will hire foreign teachers who are available in the country to teach English speaking and listening skills to children in their schools as they believe to have better outcomes. This has been a very common practice in the country recently. However, little effort is made to teach the writing skills for school children (Glass, 2008).

There is evidence that several English writing research advocates have recently attempted to solve Thai students' problem in writing at tertiary levels (e.g. Bennui, 2008; Watcharapunyawong \& Usaha, 2013; Tangkiengsirisin, 2010; Chaisiri, 2010). However, these past studies emphasized more on students' outputs while neglecting the crucial time for their inputs before such outputs can be appropriately expressed. Tangkiengsirisin (2010) for instance, concluded that Thai students' poor in writing was due to their lack of knowledge concerning cohesive devices. Watcharapunyawong and Usaha (2013) on the other hand, reported that Thai language system interfered their English writing. To explain the materials produced alone may not be effective in helping EFL students' writing skills if one ignores other factors such as "when" and "how" students are taught the skills. This is because learners need time before they can develop as writers (Kellogg, 2008). Thus, this justifies the present inquiry.

\section{Philosophical Approaches in Relation to Emergence of EFL Writing Skills}

There have been several approaches used to ground EFL writing research all of which are influenced from teaching English to NES writing theories (e.g. Berlin, 1988; Flower \& Hayes, 1981; Vygotsky, 1978). Those EFL researchers who favour the process approach would base their studies according to Cognitive School of thought. Some others are proponents of the Expressive School while others are of Social Constructivist one. None of these schools of thought have ever explained the point where EFL learners start to write in their own context.

The Cognitive School (Flower \& Hayes, 1981) has attempted to explain EFL learners' behaviours while producing their writing tasks. Examples of cognitive studies include research on different stages students experience the writing process such as prewriting, drafting and editing (Srichanyachon, 2011), time spent composing, comparison between composing in L1 and L2 and L1 use during L2 composing (Bennui, 2008; Watcharapunyapong \& Usaha, 2013). All of these empirical research deal with what is happening in the minds of EFL learners as they write. This approach does not explain when learners begin to experience and under what circumstances.

The Expressivist School (Berlin, 1988) on the other hand, emphasizes on students' liberation and self discovery as they write. Students are encouraged to write down what comes to their minds without worrying about formal mistakes. Since this approach was initiated and developed by L1 writing research, it may not be appropriate to apply it in an EFL context. This is because the ability to write freely needs some knowledge of the language either through reading, listening or interacting with others and L1 learners have this privilege. For most EFL students, writing skills remain unseen in part due to lack of adequate linguistic vocabulary knowledge or lack of proper writing education. Like the Cognitive School, the Expressivist School maintains the sole emphasis on 
writing act itself ignoring the nature of writers and their backgrounds in relation to the target language. Thus, the Expressivist School too fails to give plausible account of the time when EFL learners are ready to experience writing.

With regards to Social Constructivist School of thought (Vygotsky, 1987), the emphasis is on knowledge construction through interactions among members of the community. Proponents of this approach claim the importance of environment in shaping the learners' writing skills (Chaisuriya, 2010; Yuknis, 2010; Spencer, 2012). Similar to the other two schools of thought, the Social Constructivist School also attempts to provide accounts on what writers should do as they are writing. This approach is very applicable in teaching L1 as students already have some knowledge of the language before they are taught to write. It is much easier for teachers to create an interactive writing classroom in this context than they would do in L2 or EFL contexts. For L2 classrooms, there should be a better explanation on the point in time when learners can truly pick the target language.

The emphasis on interactions with environment is quite ambiguous for writing teachers to hold the view of Social Constructivist School. The questions might be what kind of interactions should be carried out, and at what stage? What kind of interactions or input resources yields certain type of writing skills? How long should the interactions be? The point is that how can casual interactions be different from the ones that are meant for a new construction of writing knowledge. Another flaw of this approach which seems to be inadequate to ground EFL writing research is that it overlooks the nature of EFL learners who may not ready to more advanced interactions until they have been in the field for some time. They may need to get more linguistic inputs before they are ready to begin writing. Therefore, defining when EFL students start to write in their own learning context can be beneficial as it can help writing teachers to plan their lessons carefully in order to achieve highest learning outcomes.

\section{Methodology}

\subsection{Participants}

This study is part of a larger project pertaining Thai EFL students' writing development. In the project, the researcher employed the grounded theory design in a qualitative approach as suggested by Strauss and Corbin (1998). In this design, data collection, data analysis and sampling were conducted simultaneously with the aim to achieve variability in the data obtained from the participants. At the initial stage, three English majors who enrolled in a writing course in semester 2/2012 at Prince of Songkla University, Thailand were selected to participate in the study for two reasons. First, the research objective sought to explain what made them write, the participants must be those who have already started to experience English writing. Second, from the review of literature, almost all Thai students never write in pre-university years. Therefore, university students were used as the target population. Third, English is not used in everyday communication in the region which allowed the researcher to explore how they could get into English writing experience in their own context. Then, theoretical sampling began after concepts and categories emerged from the data and the researcher found that she needed additional data to develop richer properties and dimensional variations. Therefore, four English majors from Walailak University, another leading university in the same region were required to complete the questionnaire and interviewed one month after the first data collection. In addition, one writing teacher from each of the two selected universities was also interviewed and their English curricula were collected. The data collection went on until all categories are saturated (Strauss \& Corbin, 1998).

\subsection{Instruments}

To enhance triangulation, three types of instruments were used to collect the data: an open-ended questionnaire, interview questions for students and teachers, and English curriculum from each university. The student participants were required to answer an open-ended questionnaire on their English language writing experience: reasons to learn English, the time began to learn, level and type of commitment and writing exposure, feelings about the language. Later, each of the student participants was interviewed individually. The interview questions for students elicited their past experience about English language learning in general, experience of English writing in school years, and the time when they start to write in English. The interview questions for teachers were designed to elicit their experience in teaching English writing to Thai students and challenges of teaching them the skills. All the interviews were audio-taped and transcribed for later analysis. The documentary data supplemented both the questionnaire and interview data on programmes that offer English writing in Thai universities. 


\subsection{Data Analysis}

All the data obtained from the three sources were analyzed qualitatively. They were first broken into smaller units and open coded to answer the research questions. In order to obtain a more holistic picture of circumstances when Thai students start to write in English, the researcher constantly asked questions when analysing the data than just looking for a cause and effect relationship (Strauss \& Corbin, 1998). Among the questions used were: what made them write?, who required?, where did they know writing?, how did they start?, is it same for everyone? Later, all the information was grouped according to axial coding to get more general categories that explain the time when Thai students learn to write in English. Since the data were small, the analysis was done manually which allowed the researcher to stay close with the data without software interruption (Creswell, 2008).

\section{Results}

\subsection{Thai Students and Their English Writing Experience in Pre-University Years}

When asked about their past English language learning experience through interviews and questionnaire, the seven English majors reported that they had been studying English at least 10 years before joining the university. They also informed that they had never been taught writing even in Thai (L1). This is evident in one student's report as she answered in the interview: "I just begin here (at the university), first learn writing here." Another student also explained that she was just taught how to write "simple sentences" at her previous school. Due to the mentioned circumstances, these students never experience writing in pre-university levels in Thailand. It can be inferred that English education especially at the primary or secondary school levels in Thailand did not emphasize English writing. Undoubtedly, none of them could write in English. Interestingly, one participant reported that he had an opportunity to join a student exchange programme in the USA during his high school years for a few months. He had to struggle as he had to write weekly journals as part of class assignments. This clearly indicates that Thai students will not know writing until they 'go out' to find some new experiences. The sections that follow are discussion on factors which kindle or inspire Thai students to begin leaning English writing skills in the circumstances where they have limited opportunity to get a first-hand experience with the target language.

\subsection{Factors Inspiring Thai Students to Write in English as a Second or Foreign Language}

Considering differences in contextual backgrounds of NESs and EFL learners, two major factors play crucial roles in establishing English writing experience among Thai learners. These factors are termed as conditions which are internal and external to them. The internal factors include their feeling about past English language learning experience which helped develop their motivation. The external factors are those that are related to the type of university they chose to enroll, type of curriculum introduced at the university and their willingness to improve the skills apart from required writing courses.

\subsubsection{Internal Factors}

It was uncovered that internal factors act as a major driving force which leads to Thai students to be immersed in English writing experience: their past English learning backgrounds and their intrinsic motivation to be competent in the language. When asked how do they find past English learning experience, all the participants reported that they had good English learning experience at schools thus have positive attitudes towards English language teachers who taught them in the past and maintained good relationships with them. This may be part of the reasons why they scored well in English classes though there were not writing tests. Consequently, they became very motivated to learn the language. Later, the students decided to pursue their education in English programme. One reason is that only through English programme Thai students can learn more about language as all other courses or programmes are taught in Thai language. To like English as a subject and to further explore many aspects of English language is not common among Thai EFL learners. Most of them develop English language apprehension and thus, they try to avoid anything that has to do in English. Though the students who participated in the study have a very limited exposure in English language environment, they were willing to take risks, explore more about it and begin to choose which university to enroll as English majors.

\subsubsection{External Factors}

The internal factors are those related to the individual students' perceptions and feeling about what they experienced with regards to English language in their early school years. The data reveal that external factors mainly involve type of formal education they received as English majors in Thai universities. These include type 
of university they enroll, the curriculum design, and their preferences in taking additional writing courses apart from what have been required in the programme.

The data obtained through open-ended questionnaire and the English curriculum that the students were undertaking showed that type of university which these English majors chose to enroll greatly influences the degree they devout themselves to English writing experience. Each university in Thailand has its own curriculum design though the name of the programme is similar to the other. For example, the English programme at the two universities where the participants were selected for the study did not share the same contents especially with regards to writing course requirement. Students from the first university were required to register in only two writing courses: "Paragraph Writing" and "Composition Writing." Then, they can opt to enroll in one additional writing course offered in the programme if they are interested. However, writing is a difficult course when compared to other language skills such as listening, speaking or reading. Due to that, most students only enrolled in the two required courses for the programme. This is considered inadequate to be an English graduate with little writing exposure provided through formal education.

While the student participants from the first group (university) were forced to register only two writing courses in the programme, those from the other university were given full freedom to choose from many writing courses provided in the programme. It was interesting to find that before the onset of data collection, the latter already enrolled in at least three writing courses and are planning to do more in future semesters. Moreover, they exhibited high interests in acquiring English writing skills. Thus, the differences are clearly shown between being English majors at the first university and at the other as a result of different curriculum exposure.

There are also differences in English language requirement between English majors and non- English majors at universities in Thailand. The non-English majors were only required to enroll in three basic English language courses in which the teaching of writing is often excluded. In other words, these courses did not mean to introduce writing but to teach reading, vocabulary, grammar and occasionally speaking and listening activities. In addition, the medium of instruction has been Thai language. This opens a room for teachers to give more emphases on reading and translating texts from English to Thai rather than teaching the skills of reading, speaking or listening. Moreover, writing courses are made available for English majors only and are not mandatory for undergraduate students in other programmes. As a result, non-English majors in Thailand never experience writing. Figure 1 illustrates the point where Thai students begin to experience English writing skills.

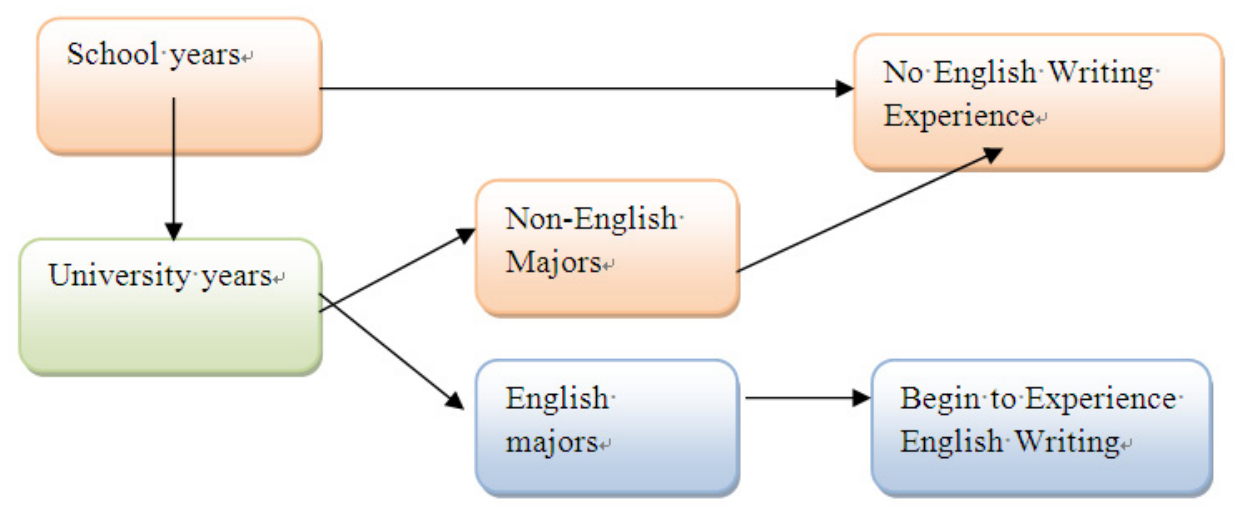

Figure 1. Emergence of writing experience among EFL learners in Thailand

It is important to note that Thai students' positive feelings, motivation from within themselves and their choice to enroll as English majors also mean they are establishing English writing skills in the near future. In addition to this, the study also found that those who were provided with a wide range of writing courses to choose in the curriculum were more proficient than those who were given a limited number of writing courses. The group with more writing exposure could produce their own short stories while the one with less exposure was trying to produce their first essay at the time of data collection. Furthermore, the group with better writing skills reported that they like and can learn better when they were 'free from teachers' force' or closely watched by the authority. Thus, learning to write came from their own willingness to improve themselves to meet their own goals. This in 
turn creates a sense of learning autonomy which is necessary in developing writing skills. Consequently, they planned to enroll in more writing courses in later semesters allowing more opportunity to advance their writing skills.

\section{Discussion}

Results of this study indicate that only those who opt to major in English will have the opportunity to study English writing in Thailand. However, very few people choose to study English as their majors. As a result, Thailand does not have enough graduates who are competent in English writing. This is also a reason why the country encounters the problem of shortage of qualified English writing teachers necessary to develop the nation as a whole. Thus, it is common for the schools to allow non-English graduates to teach English instead of none (Dueraman, 2012). This phenomenon seems to remain unchanged though English language curriculum for both primary and secondary levels by the Thai Ministry of Education. One may wonder why Thai education system introduces English writing to Thai students this late (at tertiary level). The problem is that there are discrepancies between what is written in the curriculum and what is taught in schools by the English teachers (Daily News, 2011).

According to the Ministry of Education, all schools must follow the Basic Education Core Curriculum set by the ministry in 2008. They must ensure that their teaching and learning activities are in line with the eight learning areas set out in the curriculum. One among these learning areas is called "Learning Area for Foreign Languages." Though the title itself is labled as "foreign languages," only English language is made compulsory for all primary and secondary school students as outlined in the curriculum. Upon examining it closely, it can be said that there is nothing wrong with the curriculum. There are instances indicating an equal balance in the teaching of the four language skills such as reading, writing, speaking and listening. The problem is on how they are implemented in teaching and learning activities and by whom. It is very quite shocking to many to know that all Thai students who finished their high schools in Thailand could not produce any intelligible sentences in the language they have been learning for more than a decade (Dueraman, 2013). The findings of this study also support Glass (2008) who claims that the kind of English writing Thai students learn at universities does not prepare them for future development. Their writing problem becomes more serious especially when they need to pursue higher education. There needs to be more studies on this area to obtain better explanation on the real scenario of the implementation of the English curriculum in Thailand. Results of these studies will be beneficial as they will allow English educators and teachers to reform their teaching and learning activities to a more productive way.

It is also important to note that findings of this study can add to a body of knowledge in the area of teaching English writing skills to EFL students. This is especially in terms of theoretical support where the existing philosophical approaches fail to explain. To illustrate, these theories emphasize on what writers do as they learn to write but overlook driving forces such as time and the nature of students' learning context which are as important as the writing act itself. Table 1 shows these differences.

Table 1. Differences between the existing writing theories and the current findings

\begin{tabular}{|c|c|c|c|c|}
\hline $\begin{array}{l}\text { Existing Writing } \\
\text { Theories }\end{array}$ & Ideas & Focus & Current Findings & Focus \\
\hline $\begin{array}{l}\text { Expressivism } \\
\text { Cognitivism } \\
\text { Social } \\
\text { Constructivism }\end{array}$ & $\begin{array}{l}\text { writing to discover oneself } \\
\text { stages/process of writing } \\
\text { interactions among } \\
\text { members of the society }\end{array}$ & & $\begin{array}{l}\text { time when they begin } \\
\text { to know/experience } \\
\text { writing }\end{array}$ & $\begin{array}{l}\text { time \& factors that } \\
\text { force EFL students } \\
\text { to write }\end{array}$ \\
\hline
\end{tabular}

\section{Pedagogical Implications}

Considering the factors influencing the point when Thai students start to write in English mentioned early in this paper, several pedagogical implications should be considered. First, it is worthy of note that students' past learning experience during primary and secondary school years is like planting a seed of English in them which influences their decision whether or not to continue exploring more about the language. Those with positive seeds will develop strong motivation to learn the language by enrolling in the English programme (the only programme that uses English to teach English). We believe that it is highly expected that those who enroll in the 
programme will be provided with opportunities to learn writing. Therefore, English teachers in early education should make their classes interesting enough. Otherwise, very few students will value the language while many may still remain fearful of making English writing opportunity become impossible for them. The findings also suggest that being aware of the time when EFL students are introduced writing skills is very useful for teachers. For one thing, they can plan on what to teach students at a different stage of time. For example, paragraph writing should be emphasized to English majors in Thailand though this may be too late for students of the same programme in other countries.

The problem of mismatch between the national English curriculum for basic education and the real classroom practices in Thailand should be of immediate concerns of local Ministry of Education and English educators. There should be a system established at each school in order to observe and evaluate English language teaching and learning activities. The individuals who are in charge of the activities should possess good knowledge of writing skills. This can help to provide better opportunities for the schools to review what is going on as well as identifying what is lacking in the process of teaching and learning English. Subsequently, appropriate remedies could be executed accordingly.

\section{Conclusion}

Due to the complexity of the process in acquiring English language particularly writing skills, the internal and external factors discussed above have provided important insights in understanding the emergence of English writing experience among Thai EFL learners. By improving the quality and designing effective implementation of the English curriculum in Thai education system, Thai human resources could be enhanced and trained for being more professional and effective global players.

\section{References}

Bennui, P. (2008). A study of L1 interference in the writing of Thai EFL students. Malaysian Journal of ELT Research, 4, 72-102.

Berlin, J. A. (1988). Rhetoric and ideology in the writing class. College English, 50, 477-494. http://dx.doi.org/10.2307/377477

Chaisiri, T. (2010). Implementing a genre padegogy to the teaching of writing in a university context in Thailand. Language Education in Asia, 1(1), 181-199. http://dx.doi.org/10.5746/LEiA/10/V1/A16/Chaisiri

Creswell, J. W. (2008). Educational research: Planning, conducting, and evaluating quantitative and qualitative research. New Jersey: Pearson Prentice Hall.

Daily News. (2011). Thai graduates are unqualified. Retrieved September 6, 2011 from http://tnews.teenee.com/etc/70749.html

Dueraman, B., (2013). Focus on Thai learners of English: Their self-reports about foreign language learning. International Research Journal of Arts and Social Sciences, 2(7).

Dueraman, B., (2012). Teaching EFL Writing: Understanding and re-thinking the Thai experience. Journal of Alternative Perspectives in Social Sciences, 4(1), 255-275.

Flower. L., \& Hayes, J. R. (1981). A cognitive process theory of writing. College Composition and Communication, 32, 365-387. http://dx.doi.org/10.2307/356600

Glass, T. E. (2008). The nature of English writing done by graduates of a university in Thailand. Unpublished PhD Thesis. Indiana: Purdue University.

Kellogg, R. T. (2008). Training writing skills: A cognitive development perspective. Journal of Writing Research, 1(1), 1-26. http://dx.doi.org/10.17239/jowr-2008.01.01.1

Patanasorn, A. T. (2011). Impact of learner-centeredness on primary school teachers: A case study in Northeast Thailand. The J. ASIA TEFL, 8(3), 1-28.

Spencer, J. C. (2012). Self-Made Writer: A Grounded Theory Investigation of Writing Development Without Writing Instruction in a Charlotte Mason Home School. Unpublished PhD thesis: Gardner-Webb University.

Srichanyachon, N. (2011). A comparative study of three revision methods in EFL writing. Journal of College Teaching and Learning, 8(9), 1-8.

Strauss, A., \& Corbin, J. (1998). Basics of qualitative research: Techniques and procedures for developing 
grounded theory. California: SAGE publications, Inc.

Tangkiengsirisin, S. (2010). Enhancing cohesion in Thai postgraduate students' expository writing through feedback delivery and revision. Unpublished PhD thesis: University of Nottingham.

Vygotsky, L. S. (1978). Mind in society: The development of higher psychological processes. MA: Harvard University Press.

Watcharapunyawong, S., \& Usaha, S. (2013). Thai EFL students' writing errors in different text types: The interference of the first language. English Language Teaching, 6(1), 67-78.

Williams. J. (2005). Teaching writing in second or foreign language classrooms. USA: McGraw Hill.

Yuknis, C. M. (2010). A grounded theory of deaf middle school students' revision of their own writing. Unpublished PhD Thesis: University of Maryland.

\section{Copyrights}

Copyright for this article is retained by the author(s), with first publication rights granted to the journal.

This is an open-access article distributed under the terms and conditions of the Creative Commons Attribution license (http://creativecommons.org/licenses/by/3.0/). 